\title{
Self-Transformations in Life Outside the Brackets: A Reading of Said Al-Serihi's Autobiography
}

\author{
Latifah Ayidh Albaqami \\ Taif University, KSA \\ dr.latifah@tu.edu.sa
}

This paper aims to study Said Al-Serihi's autobiography Life Outside the Brackets that is considered a new phase of cultural, intellectual, and social awareness in Saudi Arabia. The motives behind writing this autobiography according to Al-Serihi are first discussed, followed by exploring 1) the importance of selfawareness and self-transformations as an incentive for writing the autobiography and 2) the different stages of self-awareness through studying the manifestations of self-transformations and the intellectual controversy that was related to the notion of identity in the text. In doing so, the researcher tackles the following terms: alienation, splitting, and the tragedy of self and the collective sense. Additionally, the narrative construction of Life Outside the Brackets is explored, which is based on various narrative techniques including linguistic levels (direct, poetic, and mythological), time movement (accelerating the narrative via deletion and overview, and slowing it down via dialogue scenes and the descriptive pauses), and place (familiar and monotonous places). The analytical-descriptive approach is utilized to investigate the narrative techniques, and some of the psychological theories are made use of to study the selftransformations and their ideological and psychological struggle in the autobiography's setting. 
Keywords

self-alienation, self-splitting, self-transformations, Said

Al-Serihi, autobiography, the collective sense

1. Introduction

Said bin Musleh Al-Serihi, a Saudi writer and critic, was born in the AlRuwais neighborhood in Jeddah in (1953 AD). He studied in Jeddah and completed his university education and postgraduate studies majoring in Arabic language at the College of Sharia and then the College of Arabic Language at Umm Al-Qura University in Mecca, Saudi Arabia. Al-Serihi worked in the field of education for twenty years; two years in general education and eighteen years at Umm Al-Qura University. He also worked for twenty-eight years in the field of journalism, part-time and full-time. During this period, he supervised the cultural department, local affairs, international affairs, and the executive department of $\mathrm{Okaz}$ Newspaper. He also worked as assistant Editor-in-Chief and Deputy Editor-in-Chief of Okaz Newspaper in addition to writing a daily column for the same newspaper entitled (And You Have an Opinion). Al-Serihi also lectured in Arab and European capitals and served as a jury member of arbitrating the Buland Al-Haidari Prize, Al-Tayeb Salih Prize, Muhammad Hassan Prize, and Mohammed Al Thubaiti Prize.

Al-Serihi was interested in working to establish a critical discourse that reflected the identity of society and addresses literary problems to push society towards a modern intellectual renaissance and awareness. AlSerihi rushed to turn the system, which was freezing, and he stood against extremism and backwardness. He was indeed influenced by the pioneers of modernity, including Adunis ${ }^{1}$.

The importance of Said Al-Serihi's Life Outside the Brackets lies in its revelation of the writer's precise personal past as well as the events and the people who have formed his character. The book is a narrative of multiple details and events in which the writer could match between the reality and the imagination. "In a manner of speaking, an autobiography is an expression of the author's inside passion in case of his outside agitation. It is ultimately the achievement of the author's artistic presence

\footnotetext{
${ }^{1}$ Also written as Adonis.
} 
at the heart of the real world" (Sharaf, 1992, p.132-133). The reader sees the book as a turbulent presence of the self. This kind of turbulence appears through more than one level:

a. The linguistic level can be observed from the frequent use of the word (ancestors) whose presence may almost lead to the self's absence.

b. The semantic level appears through the writer's self-image as a highly transformed and resistant character.

c. The philosophical and knowledgeable level can be manifested through two opposing notions. First, the author appears to be looking for himself through two dual concepts (alienation and splitting) in a conflict between an alienated self and its relationship with the ancestors, and a splitting self that appears in his desire to oppose them. Second, however, the author shows the destruction and disintegration of the human soul. Al-Serihi resorts to writing his autobiography by "activating the power of memory and charging its memorable storage that is supposed to work in the field of autobiographies" (Obaid, 2007, p. 109-110).

Why did Al-Serihi write his autobiography? What are the motives and reasons for writing it? Considering all the motives of Al-Serihi in writing his autobiography will be difficult, so mentioning the most important ones will suffice. They are as follows:

First: Resistance to annihilation: The researcher believes that resisting annihilation is manifested through a tendency of writers to write their autobiographies in order to solidify their presence to resist the annihilation and to love the self. Al-Zahrani indicates that the deep motivation of the self to write about itself is defined by the desire to declare one's presence as a human, independent and creative character that has thoughts that about which he wants to inform others through using this narrative writing (2012, p. 95).

Al-Serihi's life has gone through many different transformations both on the personal and social levels, and these transformations are a fertile material worthy of documenting in an autobiography which is considered 
"an individual's accumulated subjective experience that became mature, and soon it formed a kind of anxiety in its owner's self, so he cannot find any means but to write it down" (Fawzi, 2011, p. 9).

Al-Serihi's cultural practice was formed in an environment full of ideological conflicts. This environment was characterized by a strict orientation that was unable to deal with the spirit of his age. Moreover, this trend continued to represent some superficial ideological issues that were not addressed in depth, claiming that it embodies the full truth. Accordingly, there was a huge hurdle that could not be overcome, where two trends dominated; a closed one claiming to have the complete truth, and another that was open to the other and keen on modernization and renewal. In this way, Al-Serihi confronted the supporters of this movement in the first real collision between them. The fact that he could not obtain a doctorate from his university for reasons related to his stance on modernity from the university's point of view has affected his personality on more than one level, most importantly, the psychological and social ones. Al-Serihi adopted a confrontational reaction to the awakening, which had a great impact in his university at that time (see Al-Serihi, 2020).

He had a great feeling of failure because he could not complete his university career after canceling his degree despite his excellence; he ranked second in KSA's high school top students and proved his genius and distinction at the university level. All these events had a great impact on the personality of Al-Serihi. The book Life Outside the Brackets is one of the first Saudi works that dared to expose the manifestations of corruption and the suppression of intellectual freedoms in some educational institutions, where the university represented a supreme official authority the individual/or Al-Serihi could not resist. The shock of not granting him the degree was a violent one that changed the course of his entire life. After that, Al-Serihi began to look for a way out of this ordeal and he found his way in journalism as a job that helps him achieve his creative self.

Al-Serihi calls the council that was convened to discuss some of his stances and intellectual orientations the Council of the Arabic Language 
Guards. It was like an absurd theatrical scene that was prepared in advance. He states:

They call in suspicion, and turned to me contriving their words that were like an ambush for me, they have finished talking about modernity and then they went on to the last stitch in the net, the last arrow in their pouch: What do you think of Adunis? He has his pros and cons. We want a clearer viewpoint. Adunis is a poet and thinker who cannot be summarized in just one judgment or opinion. In brief, do you agree with him? In a lot of what he's gone to. They signal to each other as if they have found their way, like hunters who have ensnared a prey into their ropes. (Al-Serihi, 2020, p. 117-118)

Al-Serihi's influence by the trend of modernity can be ascribed to what is known as "the anxiety of knowledge." His love of knowledge since his childhood and his deep thinking have also qualified him to be different from his colleagues and this illustrates his opinion of prophecy and his desire to be a prophet when he was at school. Consequently, he found himself in modernity as he says:

When I knew the movement of modernity, I did not care except for what I found in it: a violation of every form of saying and the mechanisms of meanings' production, an angry rejection of every established or steady way of thinking, and a great desire to say or write what is forbidden." (Al-Serihi, p. 116)

Second: a literary tradition: Al-Serihi's personality was characterized by the cultural accumulation in addition to his openness to many other cultures, without fully being immersed in them. All of these elements formed a new awareness through which he was able to achieve the interaction with the western culture and he remained faithful to his original culture which he continued to employ to overcome many obstacles in his way. Consequently, Al-Serihi resorted to writing his autobiography at this age after his literary and cultural experience developed and made him imitate a large number of great writers who wrote their autobiographies such as Life Story by Al-Mazeni (2012), I by Al-Akkad (2005), The Days by Taha Hussein (1992) and The Prime of Life by Tawfiq al-Hakim (2008).

He endeavored to make the society benefit from his life experience that is full of diverse experiences. The autobiography, as it is known, is "an effective tool that increases the fertility of our spiritual life and works to refine our personality, but we should make it a subjective experience that 
increases the depth of our inner life and serves as a moral education tool for our souls" (Sharaf, 1992, p. 17-18).

\section{Discussion}

\subsection{Self-Transformations}

As the motives were a way to find out the reasons for writing the autobiography of the author, it is also a way of penetrating the author's self, so we will review in this study the self-transformations in Life Outside the Brackets and the importance of self-awareness as a motivation for writing the autobiography and the stages of its various forms. The manifestations of self-transformations are exposed through the intellectual controversy related to the idea of identity in the text considering its multiple forms: alienation, splitting, and the tragedy of the collective sense.

\subsubsection{The alienated self}

In Life Outside the Brackets, Al-Serihi reveals a self that is difficult for the reader to recognize or define its identity according to its presence in the text and this fact opens up a wide range of questions about the nature of the self and its formation through language, or how closely it relates to the other.

In Life Outside the Brackets, Al-Serihi'a self was absent or almost absent with other selves that formed the general understanding of it and formed its life in stages of its formation from childhood to the subsequent stages. For example, in childhood, the writer describes the strong relationship between him and his mother (see Al-Serihi, 2020). This relationship was close to Lacan's mirror phase when a child begins to recognize himself by getting to know his mother's body as if he were recognizing his body in the mirror. "It is a moment when a little boy grows up, and he is pleased to contemplate his image in the mirror and see the magical compatibility between his movements and that of his opposite image" (Lacan, 1977, p. 5-6). Furthermore:

The mother's look is considered a reflective mirror; a looking eye to another looking eye and through this look emerges what Lacan called the imaginary system; the limits of truth and illusion - as Lacan says - become confused at this early stage. The ego, which is our window on the so-called real world, is actually a kind of fantasy where the one who stands in front of the mirror will 
deal with his image as a fact despite his knowing it is fake." (Eagleton, 2009, p.13)

The mother here is not meant to have the literal meaning of the word, but it extends to encompass the ancestors, and this is what appears to us in the stage of Al-Serihi's childhood, where he took from the ancestors the image of the reflected self in front of him in the mirror. "The ancestors are the perfect whole personified in his dysfunctional body, and the mirror allows him an independence that is not available to him in reality, although it is, in fact, a false self-awareness" (Eagleton, 2009, p.17).

When he was a child, Said suffered from the disease of "asthma" which obliged him to stay at home, so he was much related to his grandmother who used to read different stories for him. He had a thirst for knowledge, a sharp intelligence, and sensitive feelings. He was also fond of listening to tales and stories and did not feel shy to ask about anything. These different stories - which he heard from his father and grandmotherformed the self of Said as a child. Said's mother says as she warns her mother about the effect of these tales on Said, "I told my mother, may Allah guide her, not to distress the boy with the stories of her children and daughters ... the stories of his grandfathers are enough for him; they are filled with wolves, spiders, snakes, looting, stealing, and murdering" (Al-Serihi, 2020, p. 41-42).

But these stories did not grant Said anything except an alienated self and this is what he asserts by saying "These stories did not grant me a stony heart, but they granted me a sad heart at an early age, a heart haunted by the dead and funerals looming in front of me whenever I close my eyes and tempting me whenever I sit alone ..." (Al-Serihi, 2020, p. 42). The ritual of visiting cemeteries on the morning of the feast with his father to pray for the dead and read Al-Fâtiha had a strong effect on linking the fate of the child to the ancestors "all those whose graves I had visited in my childhood and had read them Al-Fâtiha [the first chapter in the qur'an] began to visit me when I got older" (Al-Serihi, 2020, p. 58). This union of the fate of the ancestors was a desire to protect the self from annihilation "as if our fathers were a wall standing between us and the death ... a defense that provides us with a space of life or a space of time" (Al-Serihi, 2020, p. 31). 
In this way, the self has turned to the other in an exchange of roles as if Al-Serihi resurrects the other's self and unites with it; his self disappears and hides in the other.

My entity exists fairly outside as if it is one of many other phenomena, while what's out is linked in an intimate bond with me, and it is a part of my inner being, but I feel that my inner life is strange and separate, as if a part of my being fell captive to a picture and became embodied in it. This picture seems to be able to affect my entity; an effect that stems from myself and does not stem from it at the same time, hence, in the imaginary system, it is not clear if I'm the same person or another one, whether I am inside or outside myself, if I am behind the mirror or in front of it. (Eagleton, 2009, p. 15)

Al-Serihi's self unites with those of the ancestors and this kind of unification is known by Adam Smith as the transformation in his book The Theory of Moral Emotions, or as Lacan called it (the imaginary exchange), it is a kind of resemblance or harmony of bodies (Eagleton, 2009 , p. 15). The transformation according to Al-Serihi appeared through many tales told by the writer about his ancestors, Al-Serihi used the body in Life Outside the Brackets as a language of expressing this kind of transformation. One of these tales is the dagger that hit his grandfather's shoulder; it hurt him and he felt its pain and the back of his grandfather Radhi on which he lifted the camel to protect it from the flood. All these tales cause Al-Serihi great pain that forces him to go to the hospital to be treated (see Al-Serihi, 2020). The transformation is also embodied by his internalization of the qualities of his ancestors despite him being civilized. He says: "A few days earlier I had woken up, maybe it was an old Bedouin who woke up and had an overwhelming need for a glass of camel milk and I was not really the one who liked the milk of the camels ..." (Al-Serihi, 2020, p. 14), and he describes to us the lunch table on which the camel milk was presented where he says:

We were sitting at the lunch table as guests and when I stretched my hand to a glass of milk, the bearded man sitting in front of me looked and pointed out his finger warning, "take care, the camel milk hurts those who are not familiar with it." On his lips, I noticed a sarcastic smile that affronted my Bedouin pride that runs through my body. It is that man who has always spoken evil of me in his meetings and described me in his sermons by being away from the values and traditions and contradicting the usual customs. I lifted the cup to my mouth and swallowed the milk in one gulp ... I was ready then to swallow a glass of poison so as not to leave a chance for his yellow smile to question the Bedouin who drinks the camel milk with the pleasure of one licking from the tip of his 
dagger the blood of his opponent whom he shot dead... (Al-Serihi, 2020, p. 15)

It is an extension of the ancestors' souls that converge in his body and mind. His self has united with their selves, so it is a true embodiment of both self-unity and destiny: "I am all those who have died, and all those who will be born ..." (Al-Serihi, 2020, p. 87). They became wholly deepened in him and his self faded inside their selves. He says: "I would no longer close my eyes after that night unless I heard their sounds as if they were living at the bottom of my skull, and I couldn't open my eyes unless I saw their imaginations waving on the walls or peering from the ceiling of the room" (Al-Serihi, 2020, p. 69). They became living within his soul and combined in his blood (see Al-Serihi, 2020).

\section{Real self $\rightarrow$ The mother/The ancestors $\rightarrow \quad$ an alienated self}

The previous figure embodies the mirror stage during Al-Serihi's process of self-formation, which begins from self-summoning from the absence exemplified in (the mother/ the ancestors) in the stage of childhood (a real self) to end by disappearing when the self is cracked and split (an alienated self). His self-awareness in this stage is a wrong one "the identity appears to be alienated as well, where the looking ego - or self combines its elusive entity with the entity of the visible ego which is a welcoming thing in the mirror of its self-reflection, and thus it is difficult to know the truth of the self" (Eagleton, 2009, p.18).

\subsubsection{Self-splitting}

Self-awareness according to Al-Serihi appears when he realizes that the self which corresponds to himself (the phase of the mirror) is not a real self, hence, the rejection stage begins with the intervention of the third element which is the father, and this is called (the Oedipus moment) from Lacan's viewpoint. "The closed imaginary system must open up to difference and altruism; the little child has to break the mirror of his misperception to reach the scope of the self-expression which he cannot reach alone except to some very small parts of the truth" (Eagleton, 2009, p.18). Consequently, the stage of getting away from the effect of the ancestors begins, where Al-Serihi made of this self in the text a topic of constant research that takes the characteristic of appearing at a time and hiding at another, "although the identity may seem in its transformative 
appearance responding to the principle of altruism which is often embodied by the supporters of postmodernism, and if it seems always connected to the status of the other, it is inseparable in any case from the unified ego" (Laberge, 2011, p. 393-395).

The self appears trying to get rid of the mother's or ancestors' power and to work on the centralization of the self or the ego in a self-made framework. "I looked at my face in the mirror, I was divided into two parts, a Bedouin looking squinty to the urban and splutters: 'the city has spoiled you, you run in horror from its dogs and you were the one who saw the wolves of the village as just some domesticated dogs" " (AlSerihi, 2020, p. 75). The mirror transforms to be a theatre of selfrevelation; it carries the meaning of "going down to the depths of the self and to the darkest points in it" (Goyon, 2003, p. 17).

In confronting the self, Al-Serihi reaches the moment of realization/ discovery. He can hardly distinguish himself from the ancestors as he confirms:

I don't know myself. Nothing can distinguish me from those I see. I can hardly distinguish myself from those I see. I became the one who looks and the one who is looked at. I became confused between what I read and what I heard; what I have experienced and what I imagined that I had lived. The reality is no longer realistic. My reality was a mixture of illusion and truth; perhaps a mixture of illusions that do not have a single truth or a mixture of facts that do not come into contact with one illusion." (Al-Serihi, 2020, p. 84-85)

The reason for this delusion of Al-Serihi is a lack of self-awareness. He realized that what he has experienced throughout the last period from vanishing in the life of the ancestors must be corrected now "the problem was not their own problem as I claimed; it was my problem that I have been suffering from since I started seeing what their eyes do not see, but what my eyes do not see either" (Al-Serihi, 2020, p. 84). It's the thinker's strangeness about the real living; the strangeness of the soul, or as Colin Wilson called it, "the false spirit" (Wilson, 2004, p. 11). He says: "it was not my life, as if I was not the same one who lived it" (Al-Serihi, 2020, p. 90), and he says: "It is the image of our lives, but we are not its heroes" (Al-Serihi, 2020, p. 28). It is the transformed self that appears when AlSerihi realized that he is at crossroads; he has to get rid of his ancestors' effect so that he can live his own life not the life of his ancestors. "I'm no 
longer alone. I no longer become the prisoner between the brackets of birth and death" (Al-Serihi, 2020, p. 108).

The other came to contribute to the formation of Al-Serihi's awareness and the other is exemplified here in his friends Abed, Issa, and Mr. Lotfi. His friend Abed helped him raise his self-awareness through increasing the knowledge of reading that Said has loved since his childhood. The reading represented a sudden cognitive change for Said. It did not only help him form awareness, but it also formed the beginnings of rebellion and resistance of Said as a child. Abed says urging his friend to read: "They don't want us to read in order not to understand better than them, or maybe not to understand except what they are understanding, or what they want us to understand" (Al-Serihi, 2020, p. 105). This was not Abed's opinion, but it was the opinion of Said himself. "I see my face back as a child in the mirror. I see Abed's face back as if he was me. I need to see him to see myself..." (Al-Serihi, 2020, p. 106).

Abed was not the only one who ignited the rebellion within the mind of Said, but his friend Issa -the philosopher- as he likes to be described- had a role as well, "I missed the way, my friend. Do not look for yourself in them so you go astray. Look for them in yourself so you can be guided ..." (Al-Serihi, 2020, 109). Said loved to reach the truth through Issa who increased his doubt and confusion when he answered his question, "Said: Am I just an echo of them. Issa: You exemplify their stimulations; their signs that they left behind and went ..." (Al-Serihi, 2020, p. 109). Said took refuge in his teacher Lotfi Abdel-Badie who might take him away from these doubts:

I said to Lotfi Abdel Badie while leaving the classroom:

Said: Doctor I am in trouble.

Lotfi: how?

Said: You are destroying everything I have learned.

Lotfi: Good.

Said: Good! And what will happen if I lose all what I learned after many years of expending efforts?

Said: he did not answer me and left me that day without any kind of knowledge. After this situation, I spent some years endeavoring to learn how to reconstruct the ruins of my knowledge... (Al-Serihi, 2020, p. 115-116)

The ancestors were the rock that Al-Serihi had always carried over his back and soon he fell down under it; it is the Sisyphus dilemma at its 
best. "Woe to you Issa, woe to you. I can hardly bear my life alone, so how can you burden me with all this life? I was burdened with my life, and now I became burdened with the ages of all creation; I run as if I have an arched back" (Al-Serihi, 2020, p. 95-96). The character reaches the meaning of:

The relative independence of the self within a long and enormous process of transformation that keeps the individual away from his original tribal group to reach the meanings of a complete separation resulting from violent experiences. These experiences may lead another individual to reject everything that symbolizes the traditional identity of a group whose repressive culture could no longer be accepted or identified. (Al-Zahrani, 2012, p. 108)

\subsubsection{Tragedy of the self and the collective sense}

Al-Serihi went on to look for a conscious and aware self through what is known for Lacan as (the symbolic system) or (the big other). According to Eagleton:

The phase of the mirror can be considered a glimpse of the process of falling from paradise. On the one hand, this phase occurs and contains the narcissism itself which includes some self-disgust and abuse. On the other hand, the blurred boundaries between the selves enhance the competition and harmony; they are similar to the combination of identity and hostility that we can observe in cases of paranoia in which the persecuted party is the same person, and I'm an amorphous alternative, and this is what is called by Kerr Kigard as the repulsive sympathy in his book The Concept of Panic. (2009, p. 20-21)

The relationship of self (in the symbolic system) appears to us in the text parallel to the journey of the first man in his search for freedom and immortality. He is the heir to the first sin - the sin that took Adam out of paradise is described to us by Al-Serihi when he says:

I got away from the hands of the two kings. I run and they follow me. I take refuge in the buckthorn tree as I'm naked, but they catch me: is not your sin enough for you? God gave you a thousand trees, but you refused them all except for the forbidden one. The devil seduced you, but his Lord keeps looking at you. He did not prostrate to you. He was expelled from paradise because of you, so he intended to avenge you. He took you out of it as he was taken out. But I was tempted by my freedom. God created me free, so I am not forced to obey him like you. Hence, you can get the result of your being free... (Al-Serihi, 2020, p. 93)

It is the awareness of the self by the unique and free self; a self which is free from affiliations and constraints. "The transition of the self from the status of the oppressed and helpless victim in the past to the status of the 
interactive individual self in the present time is considered a tragic and radical transformation at the same time" (Al-Zahrani, 2012, p. 105).

Al-Serihi realized that the self-image reflected in the mirror should be discarded, "The perfect ego is what you should kill, as Freud states in his book Scientific Psychology Project. So, the neighbor -and he probably means the brother/sister- is our closest friend and enemy at the same time" (Eagleton, 2009, p. 21), and this is what Al-Serihi has pointed out when he uses the story of Cain and Abel as he narrates:

I am the son of the first murdered whose blood was wasted; the victim of a brother who could not agree with me. I knew now that my ancestors who had shed blood were avenging me; having great anger in their hearts. Their blood was filled with revenge. I am the son of the dead Abel, and all those whose bodies were buried by my ancestors in the caves or left as food for the wolves and crows were the sons of my brother Cain and my murderer. (Al-Serihi, 2020, p. 94)

Then Al-Serihi turns to the sin of the killer to say: "I am Cain, the killer of his brother. My hands are stained with blood, feeling ecstasy as I lick the blood on my fingers, carrying my brother's body, sharing his blood with all the four sides of the earth, whenever a drop of his blood has fallen, a cactus tree has grown" (Al-Serihi, 2020, p. 95).

\subsection{The Narrative Construction}

The autobiography presents its contents through a narrative construction based on various narrative techniques and I tackle three levels which are: the levels of language, the movement of time, and space.

\subsubsection{Linguistic levels}

The importance of language in literary creativity lies in the fact that "language is the material of the author and his means of expression" (AlHawari, 2003, p. 200) and "Language is the basis of thought, sensation, and experience, and the good writing is the twin of sound thinking; it has its importance in literary creativity" (Abu Ali, 1999, p. 65). It seems to us that Al-Serihi in Life Outside the Brackets masterfully possesses linguistic tools. Storytelling does not distract him from the beauty of formulation and the selection of vocabulary. The autobiography was characterized by both courage and reality. It was centered on the self which provided it with a deep self-dimension. The autobiography was also filled with levels of different and rich language that influenced the 
reader. "He cannot wholly affect the reader unless he masters the construction of the fictional work and also the language which is mainly directed to serve this construction" (Athamenah, 2018, p. 677).

A careful reading of the text reveals its formation of autobiographical materials and the memories of the writer and his personal experiences in an environment in which friendship and kinship relationships play the most important role in life. The relationships center on the stories of the grandmother and father about the ancestors, who appear in strange images that make the recipient in a state of amazement. We find that AlSerihi combines what is realistic with and what is imaginary in the formation of the self. The writer "borrows from the narrative storytelling the element of (the imaginary events) to reproduce the past experiences with their real, strange and amazing dimensions, and form an emotional poetic perspective that extends from the stage of childhood until the present time of writing" (Al-Zahrani, 2012, p. 106).

In the narrative retrieval, the writer relies on the actions of the past and present in conveying the event artistically and competently. These actions are employed when he brought some events of his ability to use language, "In my childhood, I often talked to my mother, father, and grandmother about real events as they say long before I was born and then laugh, I once told them about my aunt Fatima who died of smallpox" (Al-Serihi, 2020, p. 40).

The writer changes between the levels of language to convey to us the legendary levels by using the miraculous events of the stories of demons and goblins which are often evoked by the writer, like the story of Um Saleh, and the cave of grandfather Radi, my brother Amer and others. It is a combination of the daily realistic language and the eloquent one. The importance of the language stems from its ability to control the production of the individual statements of speech, and it is a major goal in all narratives as it describes the narrative and repeats it another time. So, most of the narrative works strive to derive the words from the living reality; from the language of the street and the general public in a literary style within social documents; in a realistic literary language characterized by objective personification, self-honesty, and away from 
fabrication and imagination (see Athamenah, 2010, p. 137 and beyond).

\subsubsection{Time movement}

Time in the novel is an important basis of the narrative According to Muhammad Ayoub:

We do not believe that any event can occur away from the framework of time and space; any work of fiction cannot exist without the element of time which is one of the cornerstones of the literary work. Therefore, fiction is an art that depends on time just like music. (2011, p. 143)

Al-Serihi's autobiography is considered a broad recollection of the past from a meditative perspective, "the retrieval in the structure of the modern narrative is a familiar technique which means that the narrator leaves the level of the first storytelling, to return to some of the past events" (Hamouda, 2012, p. 455), and it was also: "The retrieval of the narrator or the personality of an event that occurred in the recent or remote past, thereby interrupting the course of the events' narrative in the past" (Al-Khafaji, 2012, p. 355).

The word "remembering/remembrance" and its derivations were used in more than one place as the following: "I remembered him, can you remember? You can't remember, he remembered, do you still remember him, he reminded me..." (Al-Serihi, 2020, p. 26, 27, 30, 36, 60, 125, 126, $122,145,172,173,143,168)$. The recollection here means the desire to break with the constraints of the present, and it represents a state of conflict with the time, "and this kind of autobiography is based on the mechanism of the retrieved narrative which is the basis of the autobiography" (Al-Bardi, 1997, p. 76). Al-Serihi mentions the difficulty of his ability to remember his age: "A long time ago I could not remember how old I was. My grandchildren asked me about my age, and I did not know what to answer. They insisted to know, and I couldn't remember; so you remember everything and forget about your age ..." (Al-Serihi, 2020, p. 33). Moreover, he says:

I used to wonder how old I was; all the official documents have a specific date of the day, month and year for my birth. Although I doubt all those documents, I remember some events that happened before long ago. I remember them very well as if they had happened yesterday without being confused. I remember them in my old age as I remembered them in my childhood. (Al-Serihi, 2020, p. 39-40) 
There is one of the retrieving painful examples that remained in his memory and which is exemplified in some of his childhood memories, including his inability to play with his peers, "I remember my childhood friends, when I would decide to play with them, I could not run like them, and the asthma I was suffering from did not give me the ability to participate in playing with my peers as a child" (Al-Serihi, 2020, p. 29). The author employed the external retrieval technique when he tells some of the stories of his predecessors. The importance of this external retrieval lies in it giving a clearer picture of the characters' past, and the external retrieval "goes back to before the beginning of the novel" (AlNuaimi, 2004, 34), and "it occurs outside the time limits of the literary work. The narrator resorts to it when a character appears in the literary work to tell us something about its past" (Ayoub, 2011, p. 170).

This kind of external retrieval can be exemplified in the story of cousin Salema's death where he says:

While I was sitting sadly on the doorstep, my mother asked me why I was sad, and I began to talk about my aunt Salema. She went out to take care of her sheep while carrying her child who was not more than a week old. She stumbled on her way to the pasture, and her child fell from her hands on the stones scattered on both sides of the road...I told my mother while I was crying, the blood was dripping down his head and he was crying. My aunt Salema asked me to take care of him, and she went to bring a rag to bind his head, but he died before she came back. Calm down, my dear son. This story had taken place a long time before you were born. But I still remember it. My dear, you remember it because you heard your father when he told it to us ... (Al-Serihi, 2020, p. 43)

The writer moves to use anticipation to organize and develop the narrative process and make the reader avoid confusion and misunderstanding. Anticipation is defined as "a hint of one or more events that will occur after the present moment" (Prince, 2003, p. 186) and it is also known as "penetrating the future, seeing the target or its features before the actual reach to it, or pointing out to the end before seizing it" (Al-Nuaimi, 2004, 38). One example of anticipation appears in his talking about the district of Al-Ruwais in which Al-Serihi was born and which was his place of growth. It will witness his burial as well. According to him, it is (the brackets of birth and death). The tomb of alRuwais witnessed the burial of the dead from his acquaintances and 
friends. He states:

They all died, and I remained alone waiting to die. I imagine my coffin carried on the necks. I raise my head a little bit. I try to see one of my companions among the mourners, but I do not see any one of them. I try to see again but I do not see any of the mourners, and my coffin is walking alone on the winding road towards the cemetery of Al-Ruwais. (Al-Serihi, 2020, p. 32)

Another example appears in his talk about the day of resurrection when he met his grandmother, his sister Saliha, and his granddaughter (See AlSerihi, 2020, p. 96-97). If we follow the evolution of time and its significance in the text, we will consider two types of time: external time and psychological time.

\subsubsection{External time}

Al-Serihi's autobiography is a mixture of the past and present in which the past dominated the events "I am the past and present at the same time; I am all those who died and all those who are born" (Al-Serihi, 2020, p. 87). The writer did not adhere to the chronology of events where he began from the stage of old age moving to that of childhood in a selfrevelation that we can see on the first page of the autobiography when he dedicated a whole page in which one sentence is written in capital letters which is "To the memory of all those who are living inside me" (AlSerihi, 2020, p. 5). This initial introduction of the phrase and its signing in the name of the writer is intended to make the reader contemplate the memory of those who live inside him in a reference to those absent/present people who lived inside him through a dualism that materialized (the absence of the body and the presence of memory). The verb 'live' and its association with the pronoun 'me' made his existence linked to their own existence and created a reflection of their influence on his life which suggests the presence of the self through the other.

Therefore, time in Al-Serihi's phrase at the beginning of the autobiography text has become the time of others who lived inside him not his own time that he recalls its writing.

Instead of the others' becoming part of the autobiographer's time, the self has become a part of the others' time. This observation cannot be understood without penetrating the self-formation of Al-Serihi's autobiography, discussed in the previous section. There is also the 
sentence that goes: "These papers were written in a time that may come, and may not come" (Al-Serihi, 2020, p. 7). In this anticipation of time by the writer, there is an anticipating vision of the time of storytelling in which he lived and another time that has not been lived yet. The title page contains a picture inspired by the past; a picture of an old house on which there are clear traces of time and an imagined picture of the writer, and this is what the publishing house referred to in a note mentioned behind the page of the title in which it states: "The cover is the idea of the author in which he imagines himself as an old man to be identified with the writers." The fact is that Al-Serihi evoked past times through his return to the time of childhood and to previous and subsequent social and historical events related to the time of storytelling. Al-Serihi left the commitment to chronological order beginning from his birth to the time of writing; each period of his life is an extension of the past. This order in which the time of storytelling differs from the time of the events is what makes the style of storytelling in Life Outside the Brackets closer to narrative storytelling than to the storytelling of self-translation. Hence, the chronology of time is subject to the association; we do not notice titled or numbered chapters that inspire the reader to recall other times in the process of retrieval.

\subsubsection{Psychological time}

Psychological time is the time of sadness, pain, fear, and death. By recalling some of the texts, the psychological time and the author's psychological state of grief and joy are both exposed. For example, Said describes to us his feelings of sadness and pain when he laid his mother to rest and his sorrow for not being able to kiss her because of the grave, that kiss which is still stuck on his lips (see Al-Serihi, 2020). Among the other sad situations is the one in which the hardliners questioned his patriotism through the winking and slandering that appeared in many of their videos and publications and their great impact on his children, "Thank God that their names bear the last title in my name, Al-Harbi, so no one knows that they are the sons of Al-Serihi whose mentality is warned against in those publications and videos" (Al-Serihi, 2020, p. 22). Another situation is when he says: "There was nothing that can hurt me except those who support me and then have no problem to describe me a 
victim as if they endorse their victory over me without realizing this fact" (Al-Serihi, 2020, p. 132).

\subsubsection{Techniques of accelerating narration}

The writer resorts to the use of the deletion technique which requires dropping a long or short period of time in the story to skip a certain time. It is a means that plays a crucial role in accelerating the narrative and it has two types: explicit deletion "in which the time is expressly declared" (Bahrawi, 1990, p. 159), and implicit deletion "in which "the narrator does not announce the time period deleted, but we understand it implicitly by focusing and linking previous and subsequent situations" (Bahrawi, 1990, p. 162). One example of the explicit deletion is exposed when he says: "I remember the small details of things that passed for decades and other trivial things, and I forget the names of my grandchildren. I forget the food that I ate yesterday." On the other hand, examples of the implicit deletion are noticed in his sayings "I got older, but I remained that child who closes his eyes and make his own stories" (Al-Serihi, 2020, p.49), "I couldn't ask him how he came while many decades have passed since his death" (Al-Serihi, 2020, p. 60), "The body of the lifetime is lying next to me on the bed. I see the beginnings and endings. Years are scattered around me like dice cubes" (Al-Serihi, 2020, p. 87), and "The age passed and I was still in my formative years, I get my hand close to my nose from which the smell of musk, eucalyptus and ambergris diffuses; this smell has not left my hand since I laid my mother to rest" (Al-Serihi, 2020, p. 182).

\subsubsection{Techniques of slowing narration down}

\subsection{The descriptive pause}

The writer returns to slow down the narrative by his use of the descriptive pause technique when he describes the retrieved scenes of life. Al-Serihi describes the world of reading which helped him to penetrate different worlds and his desire which urges him to recognize and know this world. He found no way to do so except through the world of books, so he describes the books as a lover who describes, feels, and listens to his beloved. "I open the secret door of the books then I read. The words have a smell and have a texture as well. Within their letters, 
there are hiding laughs and whispers that I crave to hear and do not hear" (Al-Serihi, 2020, p. 103). The word "I crave" tells us of the unbridled desire that drives the writer to read; it is this world in which the words turn into feminine bodies the writer enjoys seeing them. He describes this world saying:

The words have eyes, lips, breasts, thighs, and black hair spilled on bare shoulders. I reread the words as they are combined or separated, word by word. I whisper them like someone who desires to be heard. I taste the words on my lips and touch them with my fingertips. There is a tremble that goes through my body, and I close my eyes and imagine them naked in the catacombs of tales, winking at me so I melt with pleasure and shyness. (Al-Serihi, 2020, p. 104)

This world continues to confuse the writer; when he allows it to affect him, everything turns to be good like a paradise from which he becomes filled with disappointment and pain. "I fell helplessly at its door, but all my efforts become in vain" (Al-Serihi, 2020, p. 104).

\subsection{The dialogue scene}

The author/narrator resorts to slowing down the narrative in his use of (the dialogue scene) technique in many dialogue scenes that took place between the narrator and several characters; some of which were predominantly humorous. For example, the visit of Said's school to the zoo:

The school children spread throughout the garden. They were not attracted by anything except to the section dedicated to the monkeys. Abed, on the other hand, went to the deer barn; no one asked about its place, but he went to it without having any attention to others.

Said: they have a beautiful shape, I told him, so he put his finger on his lips pointing out that I should shut up, and he pointed out with his hand to sit next to him. I sat idly looking to a group of deer moving in the barn.

Abed: keep looking at just one as I'm doing.

Said: I didn't know why he asked me to do that, he broke his silence and meditation and turned to me.

Abed: Do you know what I'm thinking about? Do you remember the story of the crazy Qais that I gave to you?

Said: yes, I remember it. The story of the one who loved a girl named Laila and he got crazy because of her. There was a series about this story on the radio. Abed: One day Qais was sitting in the desert, he saw a deer and wrote poetry about it because it looked like his beloved Laila.

Said: Ok and then?

Abed: I am meditating on the deer so that I can know and feel what Qais felt 
and what let him write poetry.

Said: But he was loving a girl and he was thinking about her when he saw the deer... Abed asked me again to meditate on the deer.

Abed: Choose the most beautiful one and keep looking at it.

Said: He stared back again at that deer, and I stared at it as well. He turned to me and said ecstatically:

Abed: Do you know? I felt that it looked like one of our neighbors' girls, what about you?

Said: I felt that it looked like Sohaila.

Abed: Is she one of your neighbors' daughters?

Said: No, Sohaila is one of my grandmother's sheep. (I laughed)

Abed: He looked angrily as he insults me and said, you don't have anything to think about except your grandmother's sheep... (Al-Serihi, 2020, p. 110-113)

\subsection{Place}

Place has a particular importance. According to Descartes, it is the extension in the three-dimensional world. And according to Newton, Clark, and Plato, place is the container of things with the addition of specific characteristics that are: infinity, eternality, and antiquity. On the other hand, Kant sees that the place releases a call for awakening the mind. In fact, there is a preconception in the human mind about the nature of the place, but sociology sees otherwise. Durkheim says: society is the basis in determining the concept of the place, and therefore it needs the existence of social media that can understand the reality of the outside world" (Naseer, 2003, p. 270).

The title Life Outside the Brackets combines the elements of time with space as frameworks for the story of the author's life with the implicit reference to the quality of that life. The title summarizes the content of life and its impediments/restrictions included in the word 'brackets' which came to indicate the difficulty and hardship the writer's life included. According to Hamouda:

The description of the place is, in fact, a different mental image among novelists, whether it was a simulation of a real place or it was different, and it is linked to the perspective of the narrator, i.e., his view of the relationship of the place to the accidents and characters, and it is also linked to the narrator's expressive ability and the goals he wants to achieve. (2012, p. 97)

The place has exemplified great importance and a special dimension in Al-Serihi's life. The place was formed by the diversity of natural spaces that were varied between the familiar and the dreary. The writer depicted his life and conveyed his events into an interesting account of all the 
details of his life. The sea comes at the forefront of the places that he mentioned carefully. The sea was associated with the dead people in Said's memory. When he recalls the stories of his grandmother, he describes how a fishing trip turned into a journey without a return. He says:

I stand on the beach as I was dazzled by the waves of the sea. I get close and retreat from it. Whenever a wave came near to me, I fled to the sand. On the horizon, I catch sight of a ship's spectrum manipulated by the waves, and then it begins to sink little by little. I see men running from side to side within the ship, and others fall into the sea, so they are received by the waves and whales. I hear a man screaming: your dream has come true Om Hussein. (Al-Serihi, 2020, p. 50)

"The narrator in his use of the living reality chronicles these places with the scenes and images that confirm and enhance the nature and seriousness of the narrative" (Athamenah, 2018, p. 674). Al-Serihi recalls the city of Jeddah in which he lived, and specifically the neighborhood of Al-Ruwais. He recalls this empty land which is a place to play with his friends as he says: "This empty land was no more than a white land in the middle of our homes in the neighborhood of Al-Ruwais. The children use it as a playground for them, and when it rains, this empty land turns into a lake in which they wade, and if the water became dry, they would make the clay they desire from its mud" (Al-Serihi, 2020, p. 70).

\section{Results and Conclusion}

The paper has concluded the following:

1) Al-Serihi recalls in his book the imaginary events, autobiography, stories, memories, history, and poetry as the basic framework he adopted for the work itself.

2) The reader of the book finds a disturbed presence of the self, manifested on more than one level, including the linguistic one, which can be noticed through the frequency of the word 'ancestors' in whose presence, his self is almost absent. On the semantic level, this appears through the picture drawn by the writer of the highly transformed and resistant character. On the cognitive and philosophical levels, it appears in the face of two opposing conceptions: a perception in which he looks for himself through the two sides of the dichotomy (alienation - fission) in a conflict 
between his excluded self and its relationship with the ancestors, and which is divided through his desire to rebel against them and another perception in which he presents what the human soul has fallen into from the destruction and dismantling.

3) The autobiographical novel is of a documentary value that embodies the concerns of the generation of modernity in Saudi Arabia. Al-Serihi writes his autobiography in the belief of selfworth and resistance to annihilation.

4) The cultural practice of Al-Serihi was formed within a space controlled by a struggle between radical political ideologies that could not keep pace with the zeitgeist. This struggle has revolved around superficial and ideological issues that have not been discussed in depth, a trend closed to itself that claims possession of the full truth, and a trend that is open to the other, thirsting for modernization and renewal, represented by Al-Serihi.

5) The self-appeared absent or almost absent with other selves in Life Outside the Brackets that formed the general understanding of it and formed its life in stages of self-formation from childhood to the subsequent stages. For example, in childhood, the writer describes the strong relationship between him and his mother. This relationship was close to Lacan's mirror phase when a child begins to recognize himself by getting to know his mother's body as if he were recognizing his body in the mirror. The self was formed at AlSerihi through summoning the self from the absence represented by (the mother/ancestors) in childhood (a true self), to end with fading when the fracturing and fissioning of the self-occurred (the excluded subject). He realized that the self that identifies with itself (the mirror phase) is not a true self, so the stage of rejection begins, with the intervention of the third element, the father, who is in Lacan's view (the oedipal moment). It always takes on the character of appearing at one time and hiding at another time. AlSerihi tries to search for a conscious subject through what is known by Lacan as (the symbolic system), or (the great other). And AlSerihi realizes that the image of the self-reflected in the mirror should be discarded as Freud goes on in his book A Scientific 
Psychology Project.

6) The observed self-transformations in Life Outside the Brackets do not indicate an alienated self in general, but they indicate a coherent conception to complete the construction of the integrated identity of the individual. According to Al-Serihi, the identity "is built and rebuilt in an interactive context between the selves and each other" (Kerbrat-Orecchioni, 2005, p. 156-157).

7) Al-Serihi recalls the past times through his return to childhood and to the historical and social events before and after the time of storytelling. Al-Serihi does not commit to the chronological order; each period of his life is an extension of the past. This kind of arrangement in which the time of storytelling differs from the time of events is what makes the style of storytelling in Life Outside the Brackets closer to the storytelling of the narrative than the storytelling of self-translation. The chronological order is subject to the association, so there are no titled or numbered chapters that inspire the reader to recall other times in the framework of the retrieval process.

8) The place is considered a special dimension in Al-Serihi's life, and the place was formed through the diversity of natural places that varied between the domestic and the wild, and the writer portrayed his life reality and translated his events into an interesting narration of all the details of life, and the sea is most important of the places to mention them.

\section{References}

Abu Ali, N. (1999). 'anâșir al-ibdâ' fi shi'r 'uthmân Abu Gharıbah (Elements of artistic creativity in the poetry of Othman Abu Gharibah). Palestinian Writers Union.

Al-Akkad, A. (2005). Ana [I]. Nahdet Misr.

Al-Bardi, M. (1997). Al-sîra al-dhâtiyya fî al-adab Al-'arabi al-ḥadîth (ḥudûd al-jins waishkâliyyâtuh [Biography in modern Arab literature (Sex limits and problems)]. Fusoul [Chapters], 16(3), 68-80.

Al-Hakim, T. (2008). Zahrat al-'umr [The prime of life]. Dar El-Shorouk.

Al-Hawari, A. (2003). Naqd al-riwâya fì al-adab Al-'arabi al-ḥadîth fî Mișr [Criticism of the novel in modern Arab literature in Egypt]. Ein for Human and Social Studies and Research.

Al-Khafaji, A. (2012). Al-muștalaḥ al-sardi fí al-naqd al-adabi Al- 'arabi al-hadîth [The narrative term in modern Arab literary criticism]. Dar Safa for Publishing and Distribution.

Al-Mazeni, I. (2011). Qiṣsat ḩayâ [Life story]. Hindawi Foundation for Education and 
Culture.

Al-Nuaimi, A. (2004). Îqâ' al-zaman fì al-riwâya Al- 'arabiyya al-mu 'âșira [The rhythm of time in the contemporary Arab novel]. Arab Institute for Studies and Publishing.

Al-Serihi, S. (2020). Al-hayâa khârij al-'aqwâs: Sîra dhâtiyya lil-mad 'uu Sa 'îd [Life outside the brackets: A biography of Said Al-Serihi]. Dar Madark.

Al-Zahrani, M. (2012). Muqârbat hiwâriya [Dialogical approaches]. Makkah Cultural and Literary Club. Arab Diffusion Company.

Athamenah F. (2010). Al-sard fì al-sîra al-dhâtiyya Al- 'arabiyya: Dirâsa fî al-binâ' wal-tiqniyyât wal-naw' [Narration in the Arabic autobiographical novel: A study in construction, techniques and gender] [Unpublished doctoral dissertation]. Yarmouk University.

Athamenah, F. (2018). Tiqniyyât al-sard al-siyar dhâtiyy wa-'ab 'âduhu (Al-Ţayyib Sâlih namûdhajan): Dirâsa nazariyya țațî́qiyya [Autobiographical narration techniques and dimensions (Al-Tayyib Salih as a model): An applied theoretical study]. Journal of the Association of Arab Universities for Literature, 15(2), 669-686.

Ayoub, M. (2011). Al-zaman wal-sard al-qașași fî al-riwâya Al-Falasțîniyya almu'âsira bayna 1973 wa 1994 [Time and narrative narration in the contemporary, Palestinian novel between 1973-1994]. Dar Sindbad for Publishing and Distribution.

Bahrawi, H. (1990). Binyat al-shakl al-riwâ'i [The structure of narrative form]. Arab Cltural Center.

Eagleton, T. (2009). Trouble with strangers: A study of ethics. Blackwell.

Fawzi, F. O. (2011). Tajribatî fì al-kitâba al-târîkhiyya (al-ta 'âmul bi-shaghaf ma'a altârîkh [My Experience in historical writing (tackling the passion for history)]. Dar Al-Shorouk for Publishing and Distribution.

Goyon, C. (2003). Etudes littéraire de l'Infante Maure de Mohammed Dib. Mémoire de maîtrise, Université Lumière-Lyon2, Faculté des lettres, 109.

Hamouda, Y. (2012). Tiqanât al-sard al-qașași fî thulâthiyyat Ahmad Harb [Storytelling techniques in Ahmed Harb's trilogy] [Master's thesis]. Islamic University, Gaza.

Hussein. T. (1992). Al-'ayyâm [The days]. Al-Ahram Centre for Translation and Publishing.

Kerbrat-Orecchioni, C. (2005). Le discours en interaction. Armand Colin.

Laberge, Y. (2011). Review of Axel Honneth's La société du mépris: Vers une nouvelle théorie critique. Laval théologique et philosophique, 67(2), 393-395. https://doi.org/10.7202/1007021ar

Lacan, J. (1977). The mirror-stage as formative of the I as revealed in psychoanalytic experience. Écrits. Trans. Sheridan, A. W.W. Norton \& Co.

Naseer, A. (2003). Fâ'iliyyat al-makân fî̀ binâ' al-qașîda 'ind Dhu Al-Rumma: Muqadimat al-qașîda namûdhajan [The effectiveness of the place in the construction of the poem in Dhul-Rummah's poetry: The introduction of poems as a model]. King Saud University Journal, (15), 2, 269-316.

Obaid, M. (2007). Al-sîra al-dhâtiyya al-shi 'riyya: Qirâ'a fì al-tajriba al-siyariyya lishu 'araa' al-hadâtha Al- 'arabiyya [Poetic autobiography: Reading in the biographical experience of the poets of Arab modernity]. Modern Books World for Publishing and Distribution.

Prince, G. (2003). A dictionary of narratology. University of Nebraska Press. 
Sharaf, A. (1992). Adab al-sîra al-dhâtiyya [Autobiography literature]. The Egyptian International Publishing Company Longman.

Wilson, C. (2004). The outsider. (A. Mulla, Trans.). Dar Al-Adab. (Original work published 1956). 